\title{
The role of the social partners in digital transformation: The evidence from the trade unions perspective
}

\author{
Prof. Maria Urbaniec
}

Cracow University of Economics, Poland

\begin{abstract}
Digital Transformation forces changes in every area of the economy, including the labor market. Social partners like trade unions are the link between the employee and the employer on the labor market. The main task of trade unions is to support employees by negotiating collective agreements and work regulations, as well as interventions in cases of breaking labor law. The issue of trade union activity in the era of progressing digital transformation is poorly recognized in the literature. The aim of the article is to identify and assess the impact of digital transformation on the activities of trade unions. The applied research method is direct interviews with the use of a questionnaire. The results of empirical research make it possible to formulate conclusions regarding the actions taken by trade unions to adapt to changes in the labor market resulting from technological progress, the need for changes in their functioning and barriers to adaptation activities.
\end{abstract}

Keywords: digital transformation, trade union, labour market 